\title{
Quaternary research in China and global change
}

\begin{abstract}
Quaternary deposits of various kinds are well developed in China and provide records of almost all Quaternary geological events. With increasing interest in environmental problems, Quaternary research in China focuses mainly on understanding past environmental change. As the most important terrestrial deposit, loess has been intensively studied in recent years. Some climatic proxies (magnefic susceptibility. grain size, carbonate content, ${ }^{10} \mathrm{Be}$ and isotopes of carbon and oxygen) show climatic fluctuation during the Quaternary. Thirty-seven cycles and 110 substages have been recognized. Depth curves of these climatic proxies are well correlated with the deep-sea isotopic records, indicating their global significance. Other environmental information carriers, such as lake deposits, speleothems and sea-level change, are also dealt with in this short review. Uplift of the QinghaiXizang (Tibet) Plateau, and its effect on monsoon circulation in East Asia. is briefly summarised and the main discoveries of paleoanthropological relics are also mentioned.
\end{abstract}

\section{Introduction}

Environmental change was extensive during the Quaternary. China, with its vast territory covering the north temperate to subtropical and tropical zones, has multiple geomorphologic features, including huge plateaux, vast basins and great plains: a multiplicily of biotas, and complex geological and tectonic backgrounds. There are welldeveloped and widespread (nationwide) Quaternary deposits of many different kinds which carry records of almost all events in global environmental cvolution. Quaternary terrestrial sediments in China are well known in the work. In the west, moraines and molasse facies with the thickness up to several thousand metres are seen on the Qinghai--Xizang (Tibet) plateau and surrounding areas and in front of large mountain ranges. Coarse residual deposits occut in the rocky and sand deserts, while detrital lake sediments and chemical deposits accumulated in arid regions. A special kind of earthy deposit - loess, delivered from eolian dusts, has mantled a vast area, forming the famous loess plateau in the north-central part of China. In the east there are well-developed fluvial deposits more or less mixed with lacustrine deposits in extensive plains. Lava flows and volcanic deposits are sometimes discovered in the north-east and coastal areas. Laterite and terra rossa formed in situ by deep weathering and other red soils with more complex origins are widespread in south China. Cave deposits are scattered everywhere but mainly concentrated in south-west Chinat. Apart from the above-mentioned deposits. terrestrial detrital facies occur in some marine enviroments on the continental shelves and several sets of marine deposits with foraminitera of different ages are found in some onshore drill cores in the east. The latter are several tens to hundreds of kilometres from the present-day coast line indicating major coastline changes during the Quaternary. Holocene marine series are well developed along the coast and some other localities (Zhang and Shao, 1991). Figure 1 is a sketch map of Quaternary sediments in China.

\section{Main research areas}

\section{Loess}

Quaternary sediments are useful tools for reconstructing Quaternary environmental history. Among them. loess is in all senses the most importan carrier of environmental information in China. Loess, of tremendous thickness and in an almost complete sequence covering all the Quaternary, occupies an area of $450000 \mathrm{~km}^{2}$ mainly concentrated in the loess plateau. Palaeomagnetic dating has revealed that the Matuyama/Gauss boundary is quite near the boundary of loess and Red Clay (Heller and Liu. 1982). This strongly supports the suggestion to set the Quaternary and Tertiary (Q/T) boundary at about $2.5 \mathrm{Ma}$. Loesses alternating with palacosols reflect multiple climatic changes. Thirty-seven pairs of loess and palaeosol indicate the same number of climate cycles. in each of which a cold dry episode of loess accumulation is followed by a warm wet period of paleosol development (Ding and Liu, 1989; Liu and Ding, 1990). Depth curves of some proxies of climate changes such as magnetic susceptibility, grain size, carbonate content and isotopes with cosmic origin (10Be) indicate very well the climatic fluctuations during the Qualternary (Liu et al. 1985; Shen et al., 1992), which can also be well correlated with those of the oxygen isotopic stages of deep-sea deposits (Figure 2). From palaeosol SO to S26, or in time series from the present to 1.6 Ma BP, all the highs and lows of these curves clearly have their correspondents on the isotopic curve (from stage 1 to stage 61, Rutter, 1992). The depth-age conversion curve, obtained by Liu et al. (1994) from the Weinan loess section using effective dating methods, corresponds well with that derived from SPECMAP stratigraphy (Imbrie et al., 1984).

The distribution of loess is closely related to that of deserts. Loess is usually situated on the outside of the deserts, especially at places in the path of winds prevailing in winter and early spring. The loess-desert transition belt is fragile and sensitive to environment change. Expansion and reduction of the deserts is well recorded in this region. Apparent desert expansion took place in the last glacial maximum and is characterized by the interbedded coarse sandy layes in the loess section in Yulin (Sun, 1994). The flux of dust is positively correlated with the total area of the deserts. Major deserts in north-west China formed in different episodes during the Quaternary (Zhu and Wang. 1992) and played an important role in the formation of loess.

\section{Lakes}

Lakes are another source of information on environmental change. Besides many freshwater lakes, there are a great number of saline lakes distributed mainly in some closed basins in the north-west with elevations from 155 to $4900 \mathrm{~m}$. On the basis of chemical composition. three categories of salt lakes can be recognized: carbonate, sul phate and chloride (Chen and Xu, 1991). In the Qarhan salt lakes large amounts of halite began to precipitate at $25 \mathrm{Ka}$ and potash sed imentation at $15 \mathrm{Ka}$. These two salt layers are generally seen in lake records in west China and indicate relatively dry climatic events (Chen and $\mathrm{Xu}, 1991$ ). The fluctuation of lake levels is another indi- 


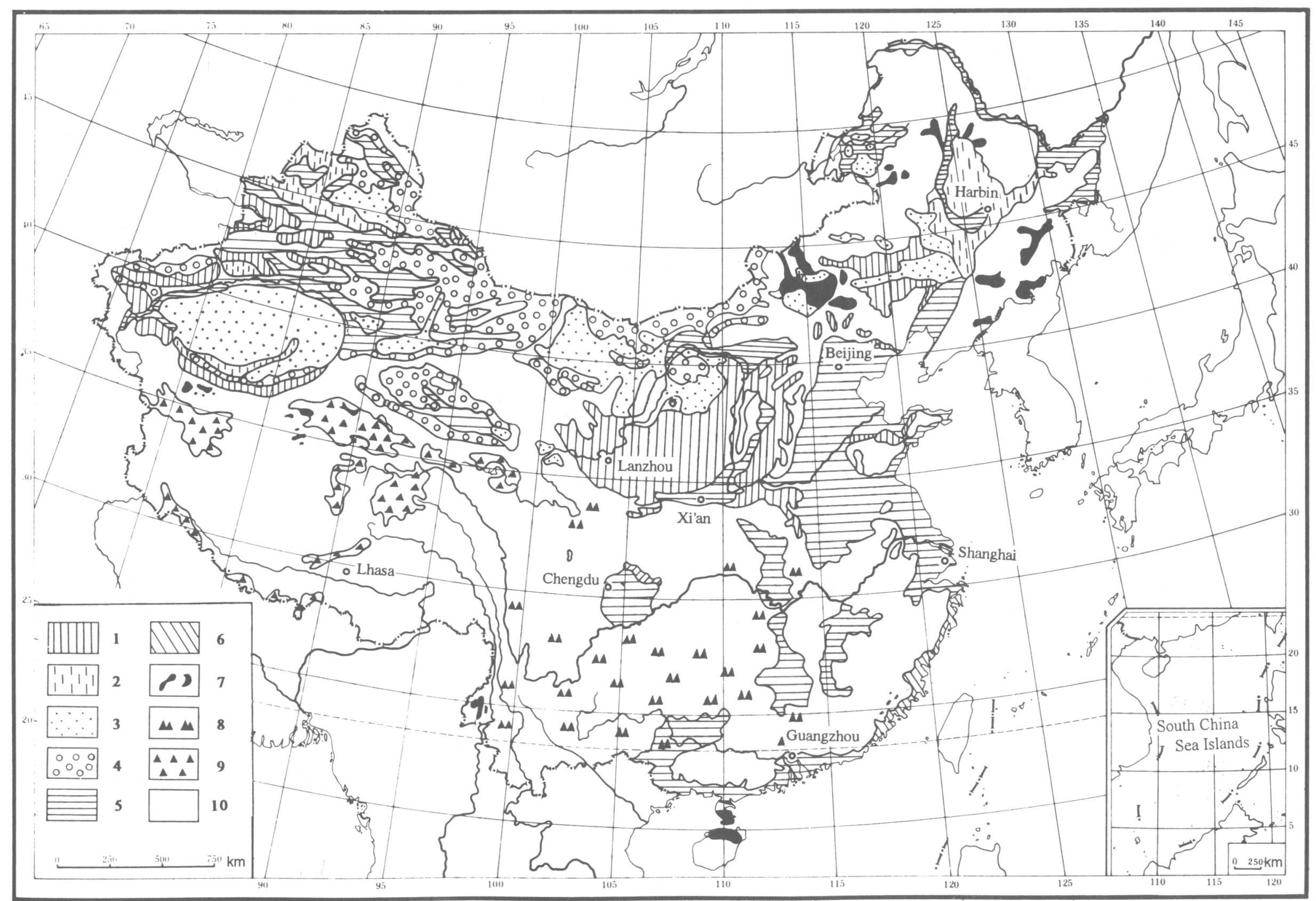

Figure 1 Sketch map of Quaternary deposits in China.

1 Loess; 2 Loess-like deposit; 3 Desert; 4 Gobi (rocky desert); 5 Alluvial deposit; 6 Marine deposit; 7 Volcanic; 8 Karst; 9 Glacifluvial-glacial; 10 Bedrock. 


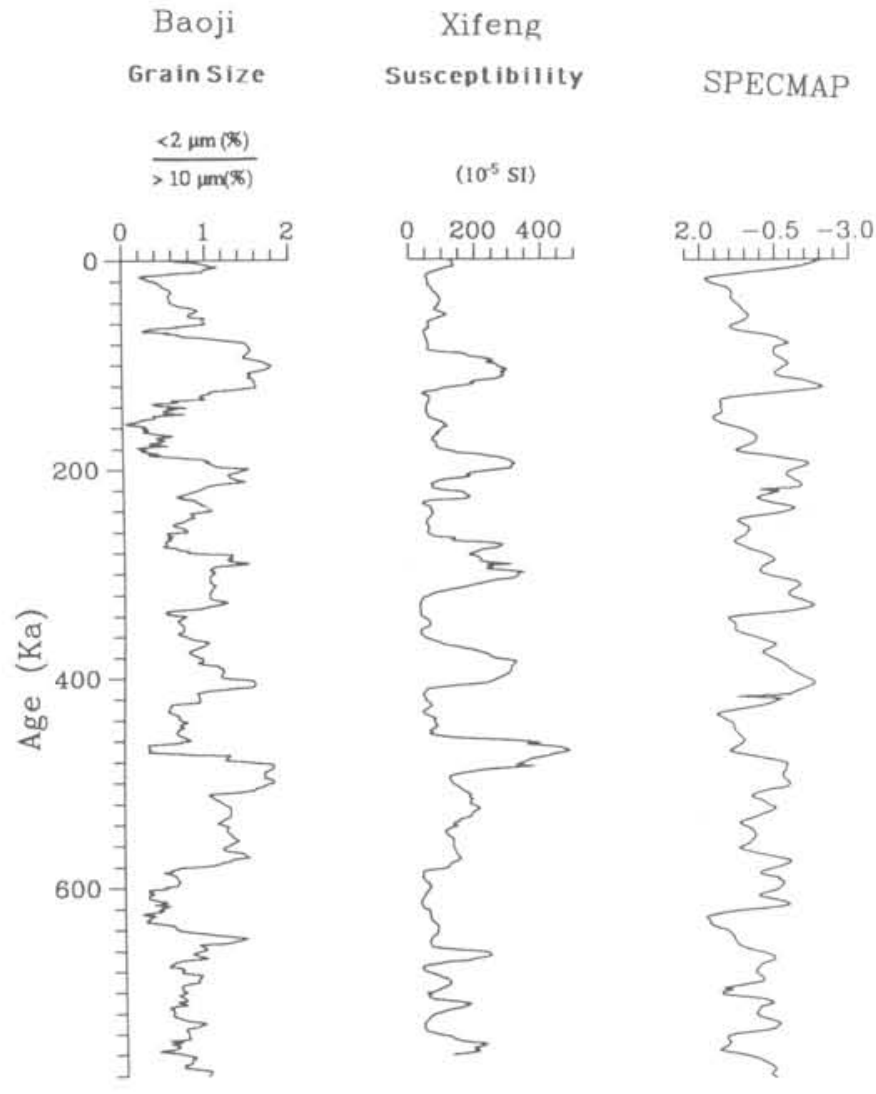

Figure 2 Correlation between the records of loess and those of deep-sea sediments.

cator of climate change. High lake level, with a relatively low salinity, is usually equivalent to the optimum climate with high precipitation. Holocene high levels appeared at $10-9 \mathrm{Ka}$ in the Daihai Lake, Inner Mongolia and at 7.5-5.5 Ka in the Ebinur Lake, west Xinjiang. Based on carbon and oxygen isotopic compositions and $\mathrm{MgO} / \mathrm{CaO}$ ratios in lake sediments, the $12 \mathrm{Ka}$ climate record from Siling Lake in Xizang (Tibet) shows the terminal Pleistocene (12-10 Ka) cold and dry period (Younger Dryas?), an early-middle Holocene (10-4.2 Ka) warm-wet period (relatively high lake level) and a late Holocene (post $4.2 \mathrm{Ka}$ ) wavy drying (and/or cooling) trend (Gu et al., 1993). We are not quite sure why there is a time difference in the appearance of high lake levels in different places. High levels at $3.5 \mathrm{Ka}$ is widely recorded in most of the lake records. Wang and Wang (1992) suggested that it might coincide with a warm period of the Subboreal phase.

\section{Karst}

The dissolution and reprecipitation of carbonate in the carbon cycle, reflecting the complex interactions between hydrosphere, atmosphere, biosphere and geosphere, formed the karst landscape (Figure 3 ), which contains a large part of the global carbon dioxide reservoir and which, in turn has a great effect on the global carbon cycle (Yuan, 1993). China is one of the countries in the world where karst limestone, ranging in age from Proterozoic to Quaternary is very well developed. In south-west China the karst landscapes have been greatly affected by both climatic change in the Quaternary and by tectonic uplift. Great potential exists in this area for obtaining datable sequences of cave deposits to determine and illustrate Quaternary changes (Sweeting, 1991).

\section{Sea level}

China has benefited greatly from its vast expanse of sea and long coast line in the study of eustatic sea level change and climate fluctuation. In Qingfeng and Xiyuan, north of Jiangsu, some sections have yielded good records of Holocene environmental history. Seven warm episodes separated by six cold episodes have been dis-

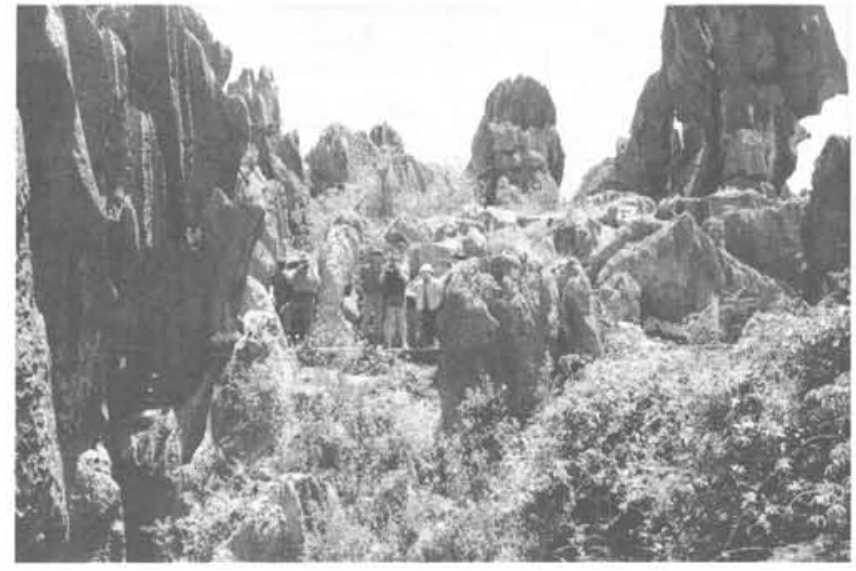

Figure 3 Karst landscape in south-west China.

cerned with each warm episode correlated with a high sea level. The highest sea level in the Holocene occurred at $6.5-4 \mathrm{Ka}, 1.5-3 \mathrm{~m}$ higher than at present (Zhao and Wang, 1992)

\section{Neotectonism}

In China the framework of Quaternary environment change is greatly influenced by neotectonism, especially the uplift of the Qinghai-Xizang plateau (Figure 4). The uplift of the plateau during the Quaternary is estimated to be about $3000 \mathrm{~m}$ or more with an average rate of 1-1.5 mm/year (Xu, 1981). Zhang et al. (1991) found that uplift of the whole plateau is still going on, based on data from repeated precise geodetic leveling surveys in 1960 and 1980 respectively. The rate of vertical crustal deformation in the south of the plateau is about $8.9 \mathrm{~mm} /$ year. The appearance of such a huge plateau splits the westerly winds into two rapid flows. One passes north of the plateau and the other, south causing anticyclones to appear above the plateau in the early summer and making north China draughty. Furthermore, this huge plateau directly influences the location and intensity of Siberian high pressure. From numerical experiments, Manabe and Terpstra (1974) concluded that this high pressure will

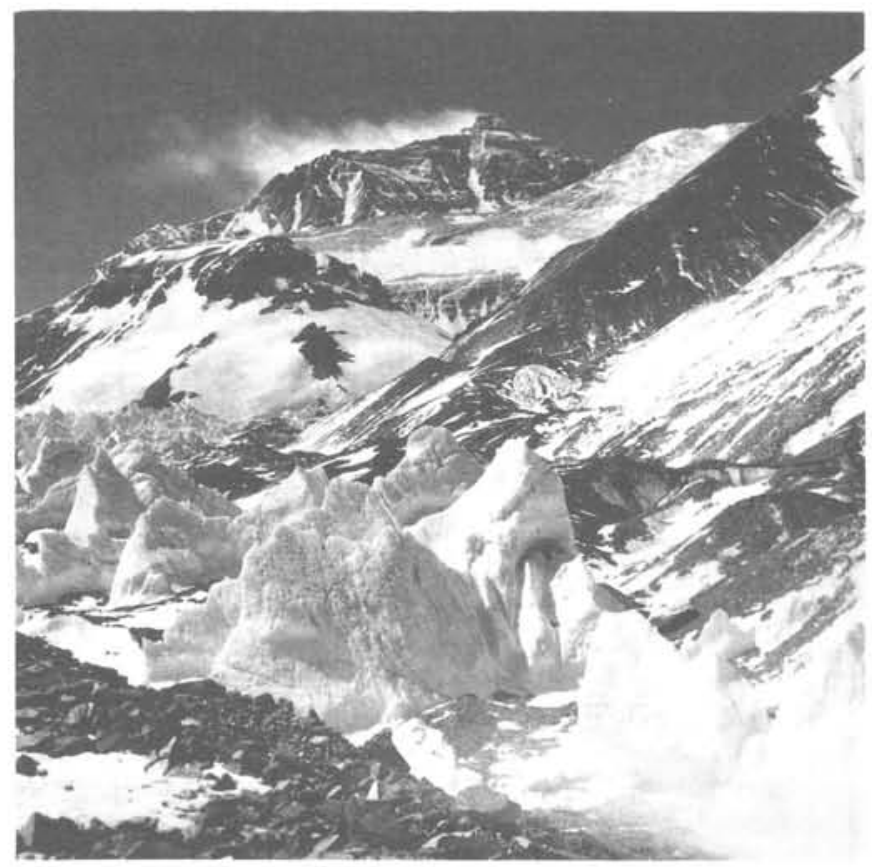

Figure 4 Mount Qomolangma (Everest). 
become stronger and locate near $45^{\circ} \mathrm{N}$ if the plateau continues to exist, otherwise it will be weak and locate near $30^{\circ} \mathrm{N}$. The high pressure is fundamental to the existence of the East Asia monsoon and of great significance in the formation and transport of dust material.

The continental glaciers developed on the Qinghai-Xizang plateau and surrounding area have provided high-resolution records of climate change in the late Quaternary. A megathermal maximum at 7.2-6.1 $\mathrm{Ka}$ and other Holocene climatic fluctuations have been found in the Dunde ice core in the Qilian Mountains (Yao et al., 1992).

\section{Palaeoanthropology}

China is not only a country where the complexity of Quaternary deposits has provided a great amount of information about paleoenvironmental changes but also a country rich in palaeoanthropological relics. Representative fossils of almost every stage in the development of mankind have been unearthed so far (Wu, 1992). Important fossils localities are Yuanmou, Lantian, Zhoukoudian (Beijing Man), Hexian, Yunxian and Yunxi (Homo erectus), Dali, Jinniushan, Dingcun Xujiayao, Maba, Changyang and Tongzi (Early Homo sapiens), Liujian, Ziyang, Zhoukoudian (Upper Cave Man), etc. (Late Homo sapiens), and Lufeng (fossil apes).

\section{References}

Chen Kezao and Xu Zhiqiang, 1991, Salt lakes in China, in Liu T, ed., Quaternary Geology and Environment in China: Science Press, Beijing pp.434 441 .

Ding Zhongli, and Liu Tungsheng, 1989, Progresses of loess research in China, I, Loess stratigraphy: Quaternary Research, no. 1, pp. 24-34.

Gu Zhaoyan, Liu Jiaqi, Yuan Baoyin, Liu Tungsheng. Liu Rongmo, Liu Yu, Zhang Guangyu, and Yaskawa, K., 1993, Monsoon variations of the Qinghai-Xizang plateau during the last 12000 years - geochemical evidence from the sediments in the Siling Lake: Chinese Science Bulletin, v. 38, pp.577-581.

Heller, F. and Liu Tungsheng, 1982, Magnetostratigraphical dating of loess deposit in China: Nature, v. 300, pp.431-433.

Imbrie, J, Hays, J D, Martinson, D G, McIntyre, A, Mix, A C, Morley, J J. Pisias, N G, Prell, W L, and Shackleton, N J, 1984, The orbital theory of Pleistocene climate: Support from a revised chronology of the marine $\delta^{18} \mathrm{O}$ record, in Berger, A, Imbrie, J, Hays, J D, Kukla, G, and Saltzman, B, eds., Milankovitch and climate: Reidel Publishing Co., Dordrecht, pp.269-305.

Liu Jiaqi, Chen Tiemei, Nie Gaozhong, Song Chunyu, Guo Zhengtang, Li Kun, Gao Shijun, Qiao Yulou, and Ma Zhibang, 1994, Datings and reconstruction of the high resolution time series in the Weinan loess section of the last 150000 years: Quaternary Sciences, no. 3, pp.193-202.

Liu Tungsheng et al.,1985, Loess and the Environment: China Ocean Press, Beijing.

Liu Tungsheng, and Ding Zhongli, 1990, Progress of loess research in China, II, Paleoclimatology and global change: Quaternary Sciences, no. 1, pp. $1-9$.

Manabe, S, and Terpstra, S, 1974, The effect of mountains on the general circulation of atmosphere as identified by numerical experiments: Journal of Atmospheric Sciences, vol. 31, pp.3-42.

Rutter, N W, 1992, Global environmental changes and Chinese loess: Quaternary Sciences, no. 1, pp.2-11.

Shen Chengde, Beer, J, Liu Tungsheng, Oeschger, H, Bonani, G, Suter, M, and Wolfli, W, 1992, ${ }^{10} \mathrm{Be}$ in Chinese loess: Earth and Planetary Science Letters, vol. 109, pp.169-177.

Sun Jimin, 1994. Environmental change of the desert-loess transition belt of North China: PhD thesis, Institute of Geology, Chinese Academy of Sciences.

Sweeting, M M, 1991, The Quaternary and world karst: Review reports, special proceedings of 13 th INQUA Congress, August 2-9, Beijing, China, pp. 22-23.

Wang Sumin, and Wang Fubao, 1992, The limnologic record of Holocene climatic fluctuation, in Shi,Y, and Kong Z, eds., The climates and envi- ronments of Holocene megathermal in China: China Ocean Press, Beijing, pp.146-152.

Wu, Rukang, 1992, Palaeoanthropological studies in China: Retrospect and prospect, in Sohn, P, ed., Korea-China Quaternary-Prehistory Symposium, pp.100-105.

Xu Ren, 1981, Vegetational changes in the past and the uplift of QinghaiXizang plateau, in Liu T, ed., Geological and ecological studies of Qinghai-Xizang Plateau, 1: Science Press, Beijing, pp.139-144.

Yao Tandong. Shi Yafeng. Thompson, L G, and Gundestrup, N, 1992, Climatic changes of Holocene reflected in the ice core from Dunde, Qilian Mountains, in Shi, Y and Kong Z, eds., The climates and environments of Holocene megathermal in China: China Ocean Press, Beijing, pp.206-211

Yuan Daoxian, 1993, Carbon cycle and global karst: Quaternary Sciences, no. 1. pp.1-6.

Zhang Lingyuan, Jiang Zhaoli and Liu Xiaodong, 1991, A study on the relationship between the east Asian monsoon and Qinghai-Tibet plateau in their formation and evolution processes, in QGERC and CHIQUA eds., The Quaternary glacier and environment of Western China: Science Press, Beijing pp.1-14.

Zhang Qingsong, Zhou Yaofei, Lu Xiangshun, and Xu Qiuliu, 1991, Recent uplifting rate of the Qinghai-Xizang plateau: Kexue Tongbao, v. 36. pp. 529-531.

Zhang Zonghu, and Shao Shixiong, 1991, The Quaternary of China: China Ocean Press, Beijing.

Zhao Xitao, and Wang Shaohong, 1992, Sea level change and its relationship with climate change and coastal evolution of Holocene in China, in Shi, Y and Kong Z, eds., The climates and environments of Holocene megathermal in China: China Ocean Press, Beijing, pp.111-120.

Zhu Zhenda, and Wang Tao, 1992, Theory and practice on sandy desertification in China: Quaternary Sciences, no. 2, pp.97-106.

Tungsheng Liu is President of INQUA (International Union for Quaternary Research) and Chairman of CHIQUA (China Quaternary Research Association). He is a Quaternary geologist and environmental geologist. He is now organizing an international group to work on the PEP II project, which is the Australasia transect and will promote the extraction of new, highresolution records with particular attention to the palaeomonsoon as a tele-connection process in tropical and subtropical regions. It will also be central to developing a clearer understanding of the influence of the Tibetan Plateau on global change.

Jiaqi Liu is Director of the Laboratory of Quaternary Geology, Institute of Geology, Chinese Academy of Sciences and SecretaryGeneral of CHIQUA (China Quaternary Research Association). $\mathrm{He}$ is active in the study of past global change. His main research interests focus on geochronology, volcanology and geochemistry.
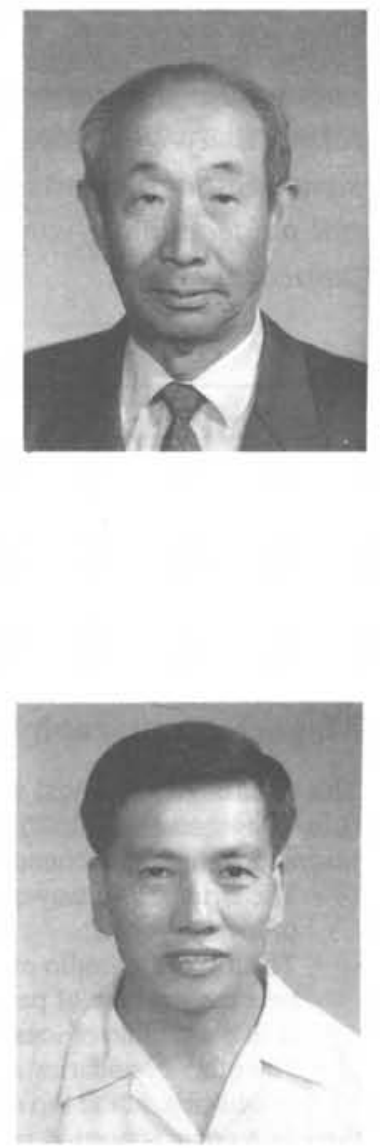